\title{
DER KAMPF
}

\section{UM EINEN \\ GEISTIGEN LEBENSINHALT.}

NEUE GRUNDLEGONG

EINER

WELTANS CHAUUNG.

VoN

RUDOLF EUCKEN,

PREFESSOR IN JENA.

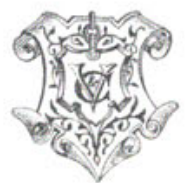

LEIPZIG

VERLAG VON VEIT \& COMP.

1896. 
